\title{
Design and development EduPocket A+
}

\author{
Norfaridatul Akmar a *, Nur Yasmin Nadhirah ${ }^{\text {b }}$, Ainul Tasneem c, Iman Sabrina ${ }^{d}$, Fitrah Nasuha e \\ Sekolah Menengah Kebangsaan Putrajaya Presint 16(1). 35900 Wilayah Persekutuan Putrajaya, Malaysia \\ a akma@smart.edu.my; ${ }^{b}$ yasminnadhirah.17@smkpp16.edu.my; ${ }^{c}$ ainul.17@smkpp16.edu.my;

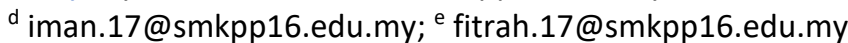 \\ * Corresponding Author.
}

Received: 4 January 2021; Revised: 29 January 2021; Accepted: 31 January 2021

\begin{abstract}
The objective of Science, Technology, and Engineering Mathematics (STEM), is not only focused on scientific knowledge and concepts but 21st century skills such as collaborative skills, communication, critical thinking, creativity and computational thinking should be emphasized in science learning. This concept paper discusses how to develop the EduPocket $\mathrm{A}+$ and this application features easy-to-grasp notes and animations to present the Physics syllabus in a simple manner. EduPocket $A+$ is an (Android APK) application where individuals are able to access notes) through interactive means as well as prep individuals to answer essay questions for the SPM Physics Paper 2. A review of the literature shows that educational games can improve student academic achievement. In addition, this learning approaches provide a fun learning environment, increasing active engagement students in learning, and increase students 'interest and motivation in STEM education. However, studies on game-based learning involving students as educational games designers or inventors are still lacking in Malaysia, especially at the secondary school. Furthermore, relatively little research has focused on the development of EduPocketA+ as effectiveness of educational games mastery of 21st century skills in STEM. Therefore, this concept paper discusses the development of EduPocketA+ that involving students in making games in learning, facilitating strategies in physics learning concepts and improve 21st century skills among students.

Keywords: 21st century learning (PAK-21), Apps EduPocketA+, student-centered
\end{abstract}

How to Cite: Akmar, N., Nadhirah, N. Y., Tasneem, A., Sabrina, I., \& Nasuha, F. (2021). Design and development EduPocket A+. Momentum: Physics Education Journal, 5(1), 94-100. https://doi.org/10.21067/mpej.v5i1.5700

\section{Introduction}

In the 21st century, various challenges such as challenges from the aspect of globalization and developments in technology communication. Thus, education plays a role which is important in preparing competent and competitive students in the forefront of this world and be able to face the challenges of the Industrial Revolution 4.0. For that, the transformation of education must take place in parallel with the current modernization of the world, especially in teaching and learning (TnL). In the TnL process, electronic devices such as the internet and computers are a tool used by educators in Malaysia. Computer not only is it a teaching aid in the classroom, but it is a tool for students to access and search information in learning in this digital age. So, that a lesson student-centered should lead to a revolution in consumption digital technology in the classroom. With the rapid development in science and technology, critical thinking skills and effective communication skills is an essential skill. Therefore, among the challenges are great to educators in the 21st century this is guiding students so always think creatively and critically. Science is not a subject who merely memorize concepts, even an understanding of science such as Chemistry, Physics and Biology are more to the understanding through experiments, inventions and brainstorming. All 21st century skills such as collaboration skills, critical thinking skills, creative and effective communication skills can be 
nurtured through activities such as problem solving and design innovation projects. According to the Plan Malaysian Education Development 2013-2025, activity-based creativity and innovation are essential, where all these activities can encourage students to constantly think of new ways of solutions and creating opportunities for his career (Ministry of Education Malaysia 2017). Therefore, PPPM 2013-2025 has given emphasis to develop creative and innovative human capital to meet national needs in the 21st century. Going through the 21st century, education plays a very important role in producing human capital that will be a catalyst towards national development. The Ministry of Education Malaysia (MOE) has introduced the 21st century learning starting in 2014. Previous studies have shown that teaching and learning strategy by digital game-based learning is effective in improving student academic achievement (Chen, 2017; Yeh et al., 2017).

This strategy is student-centered to unearth the talent and potential stance by applying critical thinking skills and use. With this, teachers and students play an active role to ensure that learning runs smoothly. Moreover, the era is now growing rapidly with a life based on technology and innovation. In particular, the world of education places great emphasis on technological developments to master 21st century learning (Kao et al., 2017). Game-based learning in STEM Education such as apps games able to improve visual thinking among current students studying the concepts of physics (Mohanty \& Cantu, 2011). In addition, study findings also indicate that this apps game method can increase student achievement and motivation in learning.

\section{STEM Education in the 21st Century}

In order to achieve the goal of becoming a developed and capable country facing the challenges of the Industrial Revolution 4.0, various efforts have been made by the Ministry of Education Malaysia. Among them is Policy 60:40, ratio of 60 per cent science students to 40 per cent literature students, Policy National Science, Technology and Innovation (DSTIN) and Vision 2020. Policy 60:40 aims to meet the needs of that workforce competent in the industry, such as scientists, doctors, engineers and technicians highly specialized. Nevertheless, according to the Strategy Report Achieving the 60:40 Science/Technical Stream Policy, this desire is still unattainable realized despite various initiatives and eye-strengthening efforts STEM lessons have been introduced (Phang et al., 2014). Between the strategy implemented is to implement various approaches new learning to increase students' interest in studying science. According to Sumintono (2017), the percentage of science stream students never more than 30 percent. A study from Phang et al. (2014) meanwhile stated that the percentage of literary stream students is higher than the science stream since 1981. However, The Malaysian Ministry of Education is still targeting student involvement in STEM by 60 percent with increasing interest students in STEM education through efforts such as upgrading laboratories school science, enhancing teachers 'ability to integrate design thinking and creativity in teaching activities and learning (Ministry of Education Malaysia, 2017).

21st century learning emphasizes the concept of learning student -centered, where students learn collaboratively with teachers and students through discussion and problem solving. So, teachers play an important role in planning activities innovative learning and learning aids to be able create students 'thinking more effectively. However, Said and Normiati (2017) reported that teachers 'reluctance to task educating and not making lesson plans is the cause primary teachers are unable to deliver that teaching and learning quality to students. The findings of this study are in line with that study conducted by Arip et al. (2014) that teacher tendencies using traditional teaching methods and not using teaching aids in PdPc will cause students to disappear focus on learning. This teacher's action will cause the student feeling bored, not interested in learning and will eventually give up disciplinary problems among students. Indirectly skills creativity cannot be nurtured throughout the deep learning process among students.

Findings from the above studies indicate that 21st century skills are very important in this Keconomy era. The issues discussed need to have an engaging and relevant learning approach to 21st century learning in addition able to attract many students to be interested in STEM fields. In game based learning, many studies use educational games as learning and studying aids effectiveness on 
concept mastery and motivation towards learning STEM subjects, especially Physics. However, less empirical studies involving students for them to create games education.

\section{Method}

\section{EduPocketA+ Design}

For the design of this game (Figure 1). Assets are created for the button function and background in the application. Graphics editor software called Procreate are used. Windows software Concepts is used to create colourful and interactive notes for each Kurikulum Standard Sekolah Malaysia (KSSM) Form 4 Physics chapter. Development of this application took place inside Microsoft Visual Studio to program codes in C\# (C Sharp) language. All the scripts created is combined and put inside a cross-platform game engine called Unity.

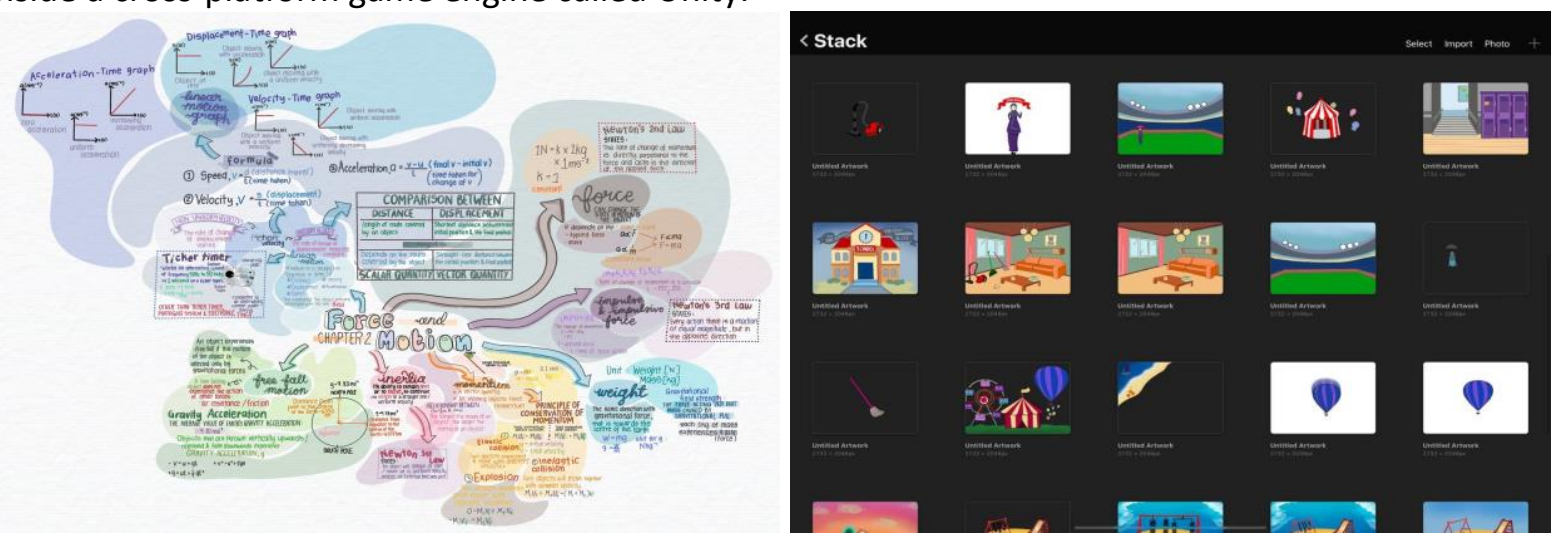

Figure 1. Notes and Assets
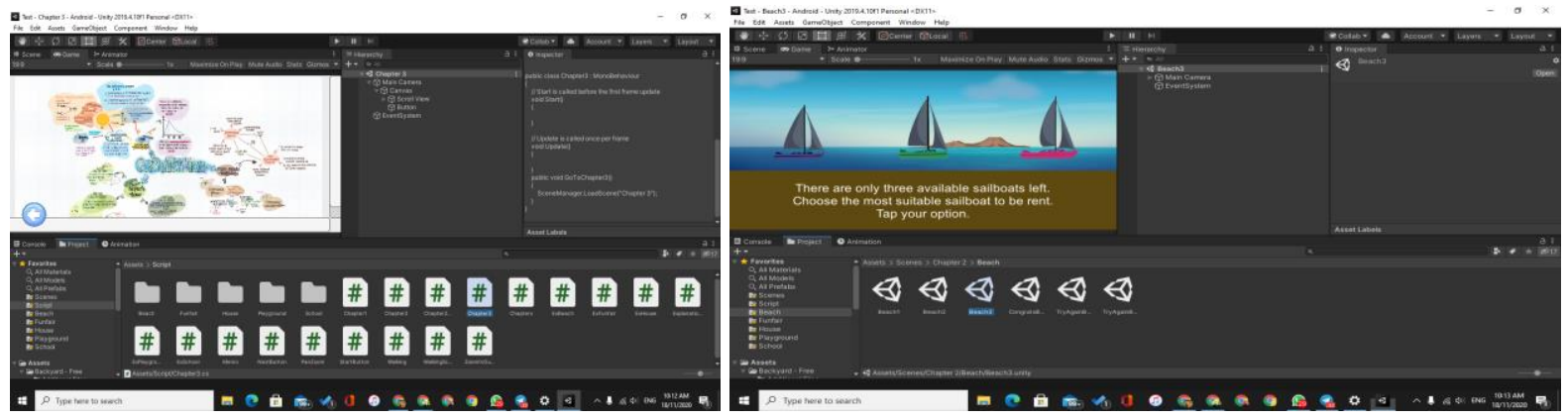

Figure 2. Microsoft Visual Studio to program codes in C\# (C Sharp) language
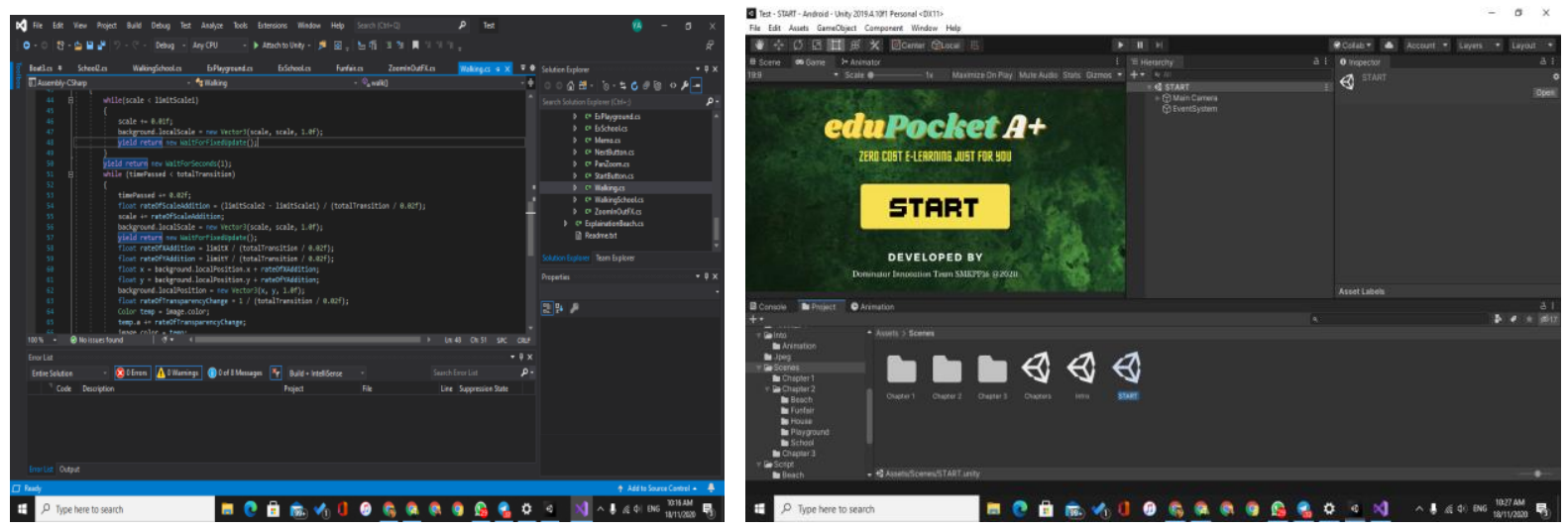

Figure 3. All the scripts created is combined and put inside a cross-platform game engine called Unity

The goal in designing the proposed game was to optimize the benefits of a EduPocketA+ in Physics Subject. In this game, the first part is that players have to strategize how they play to achieve 
goals when they are within the rules. The challenge that comes through the process of achieving the goal is limited by game rules and will make players feel fun during playing. Development of this application took place inside Microsoft Visual Studio to program codes in C\# (C Sharp) language (Figure 2 and Figure 3). All the scripts created is combined and put inside a cross-platform game engine called Unity.

How To Play

Firstly, the user is needed to choose a subject she/he wants to play Then the user needs to choose a corresponding chapter of the subject chosen (Figure 4).

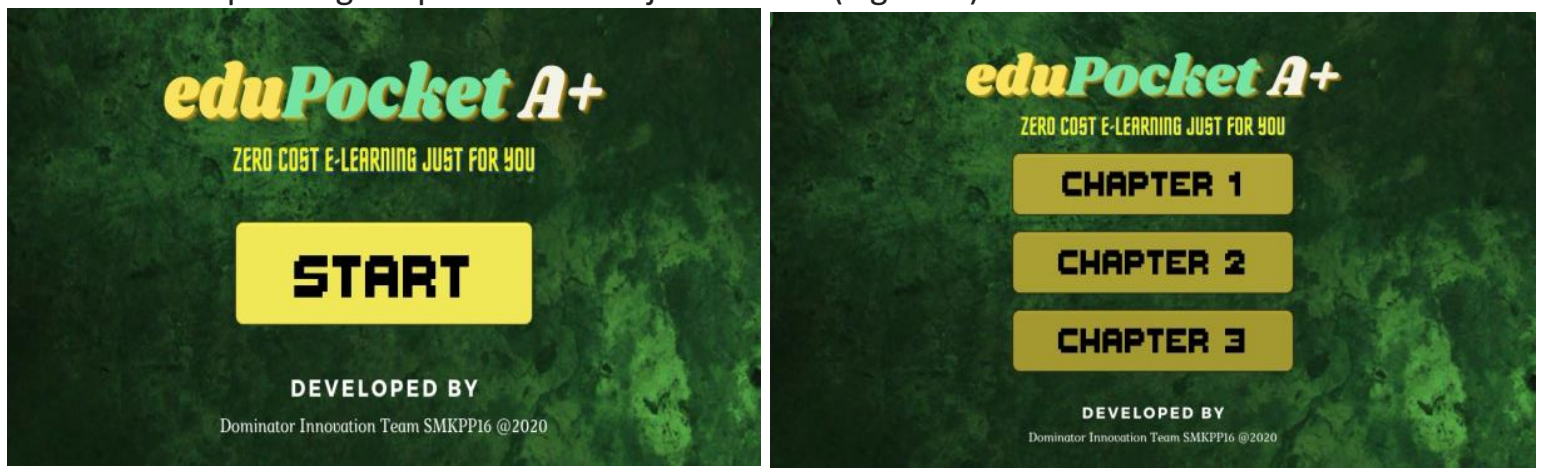

Figure 4. Starting the games

Then examples of daily life situations will be given (Figure 5), the user is able to choose any activities to their liking.
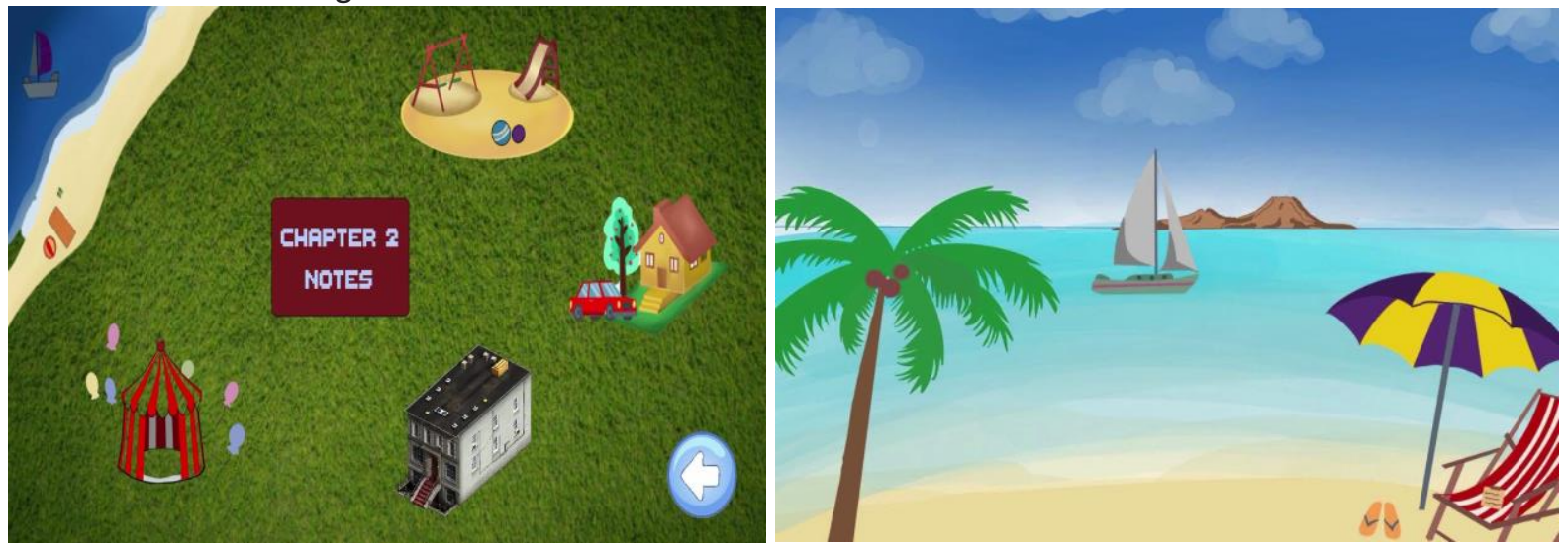

Figure 5. Daily life situations

Subsequently, a question about a physics principle regarding the activity will be asked. Therefore, the user is needed to answer the question which is categorized as a high order thinking skills question (Figure 6).
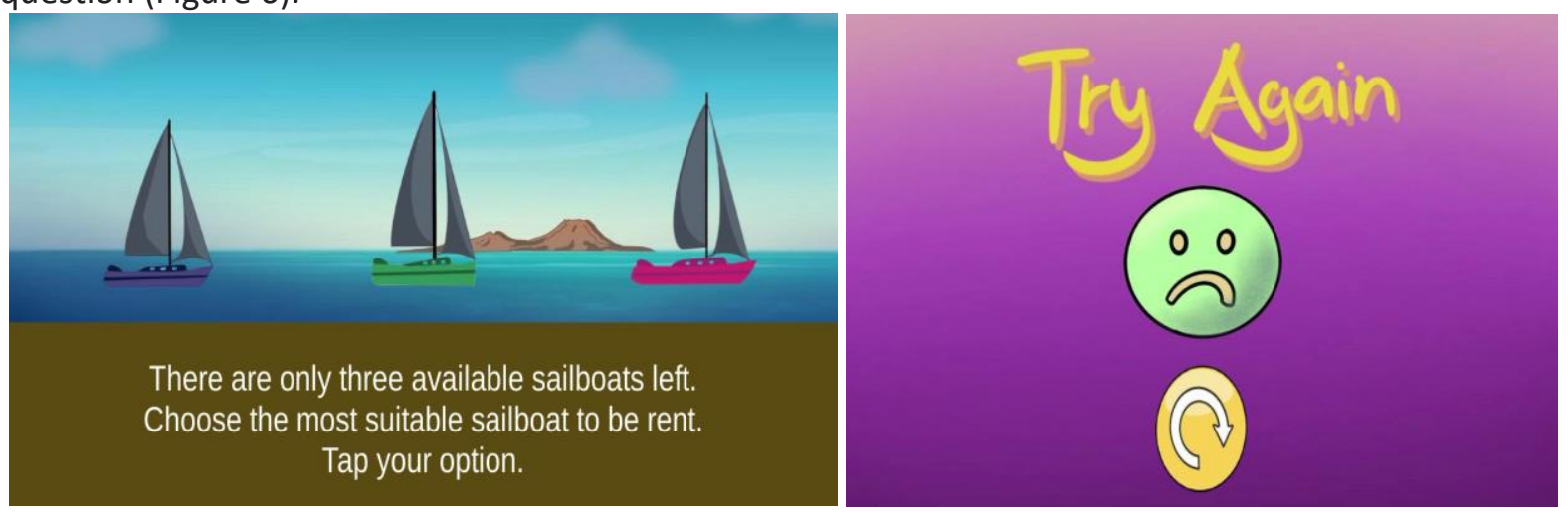

Figure 6. High order thinking skills question. 
If the user succeeded in answering the question, she/he is able to choose another activity. On the other hand, if the user got the question wrong an answer sheet will be given and a reason why the answer is most suitable in the SPM paper 2 format (Figure 7).

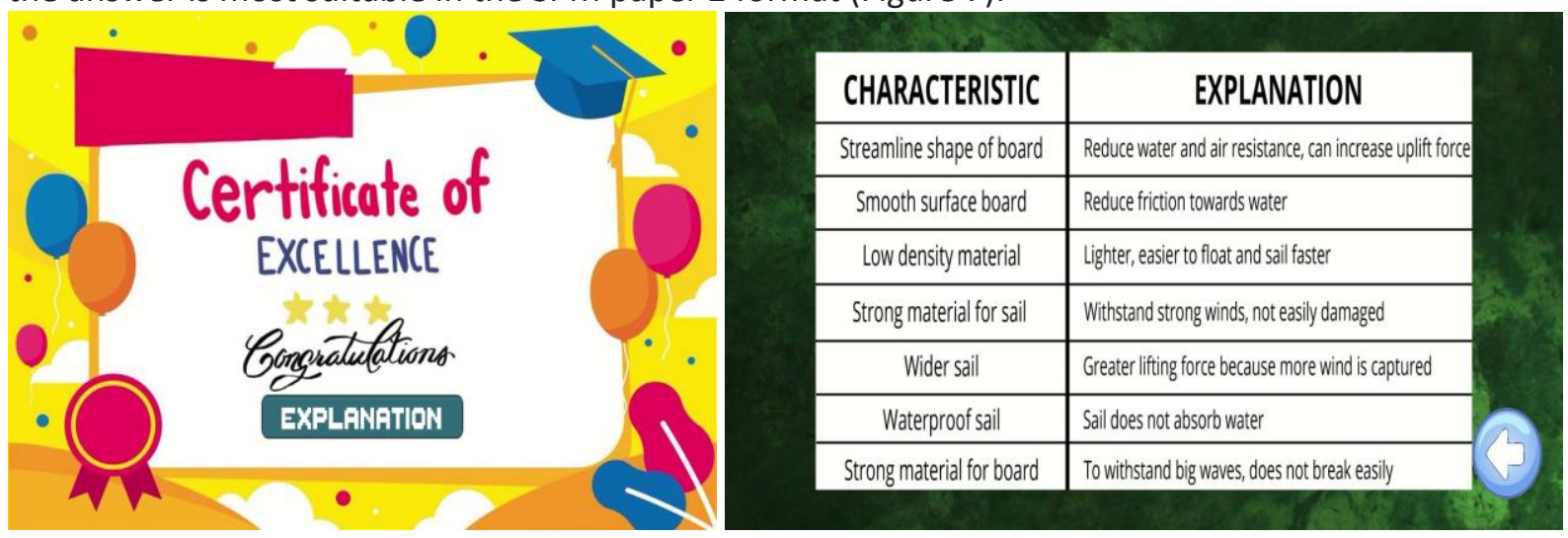

Figure 7. Certificate and answer

\section{Result and Discussion}

EduPocket A + application is targeted for high school students and teachers. We have distributed the census (which is a box of optional box questions) to students studying in Wilayah Persekutuan Putrajaya and took the science stream by asking them about the subjects that they consider it as the most challenging, which among the subjects are Biology, Chemistry, Physics and Computer Science. The census received a total of 498 responses; Biology subjects received a total of 121 responses (24.5\%), Chemistry a total of 155 responses (31.4\%), Physics a total of 380 responses $(76.9 \%)$ and Computer Science a total of 128 responses (25.9\%). There were 4 respondents who did not choose any of the options. Therefore, we have chosen the subject of Physics as the main focus for the demo of this application. The use of digital game -based learning in support student creativity (Behnamnia et al., 2020). Findings of these apps shows a positive effect on student learning. Positive effects such as encouraging collaboration (Bhuiyan \& Mahmud, 2015), improve skills problem solving (Gee, 2003; Huizenga, 2017; Hwang et al., 2015), improve student performance and confidence (Ku et al., 2014) and interest in learning (Liu \& Chen, 2013; Sin et al., 2013) clearly prove that digital games applied in teaching and learning potentially used in educational environments.

Meaningful learning is a process by which students be able to relate a new concept to the knowledge contained in cognitive structure in the student. According to Grove and Bretz (2012); Novak (2010) and, three key requirements in learning means is (i) the student must have existing knowledge about the concepts to be learned so that students can relating about new knowledge to be explored, (ii) students should be able to see the connection between existing knowledge and important concepts for newly learned knowledge in the learning process, and (iii) students should take the initiative to explore knowledge through creative means the relationship between new knowledge and existing knowledge. Hence, for ensure meaningful learning takes place in the game, students play an important role when doing something learning activity. Thus, student communication between learning materials, interactions between students and student interactions with teachers become an important element in integrating games in learning. This is to ensure that in games, students can master knowledge, master 21st century skills through designing games and being able to provide motivation to students in a learning environment that fun. Thus, three important elements in games-based learning in education are students as game inventor's education, teachers as mentors in learning and play as a learning tool to students and as a teaching tool for teachers in guiding students about the concepts that will studied. In addition, the nurturing of 21st century skills in among students can also occur throughout the learning process. The proposed conceptual framework for identifying effectiveness game -based learning on academic achievement in Physics and mastery of 21st century skills are as in Figure 8. 


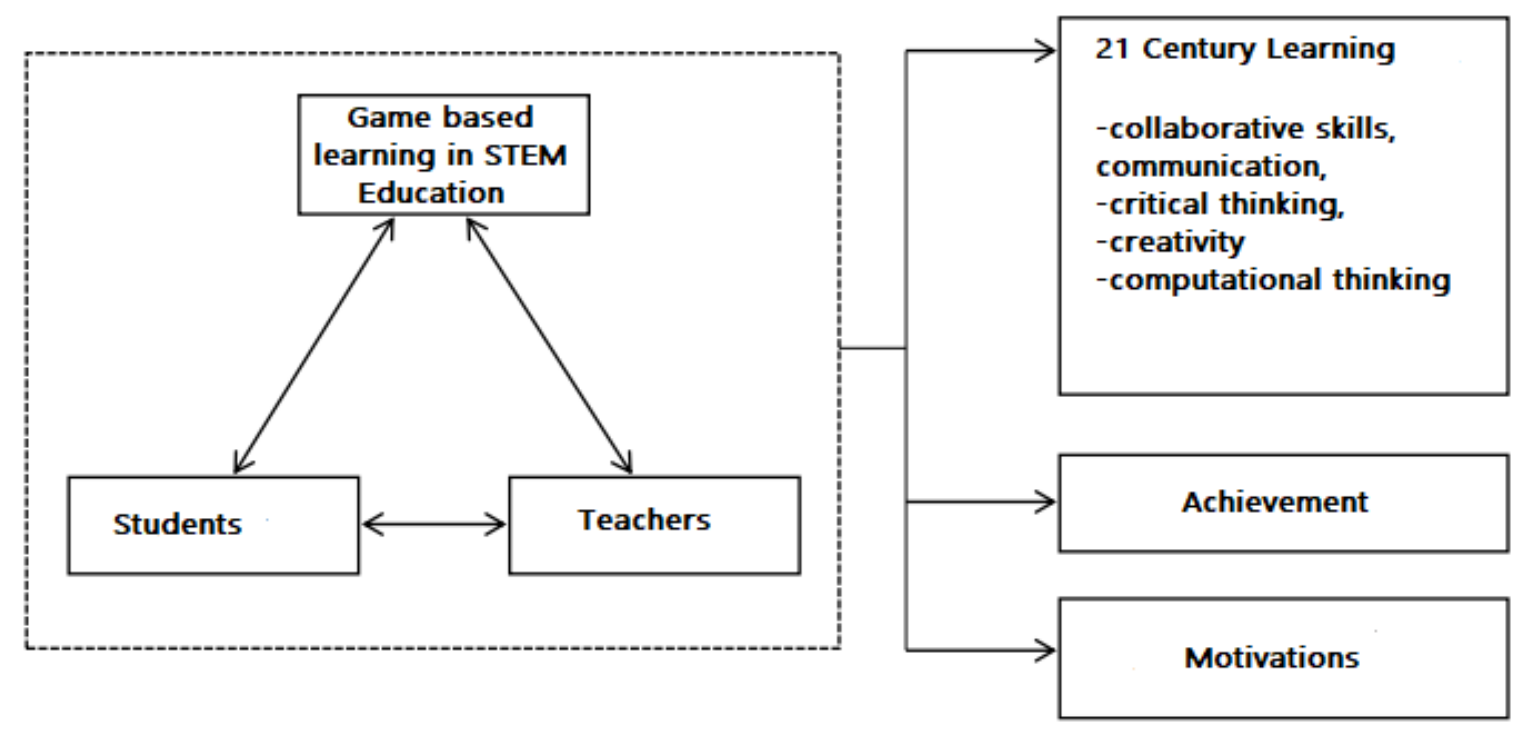

Figure 8. Conceptual framework

\section{Conclusion}

In this era of globalization, application is the best path for students. By using application techniques, knowledge is much easier to impart to students. A study found that apps make learning more effective. This is because, the information channeled is specific, direct, concise, animated, or complex graphics are not required therefore the knowledge shared directly does not require any cost. The application has created is eduPocket $A+$ can ensure the requirement. By following the fourth goal of the Sustainable Development Goal (SDG), we want to ensure that every human being successfully completes a quality, free and fair education that leads to relevant learning outcomes and effective 'Goal-4'. Previous studies have shown that based learning games are a more effective teaching strategy compared to traditional methods in improving achievement student academics, increase student motivation, engage students more active in learning. Nevertheless, empirical studies about student involvement as game inventors in learning and effectiveness of the use of games in learning to cultivate 21st century skills in circles students are still under-conducted in Malaysia, especially for students in secondary school. Accordingly, the involvement of students as inventor's games in learning are important because they can guide students to master 21st century skills such as collaboration skills, effective communication skills, thinking skills critical and creative skills as well as computational thinking. The proposed concept is hoped to give an idea to teachers, especially STEM teachers in guiding students to master 21st century skills and at the same time be able to improve student motivation and academic achievement. Thus, the study further is needed to test the effectiveness of that conceptual framework proposed in improving academic achievement and mastery 21st century skills among students.

\section{References}

Arip, M. A. S. B. M., Sa'ad, F. B. M., Jaapar, N. B., Ali, K. B. M., Athdzar, N. H. B., \& Rashid, W. N. B. W. A. (2014). Faktor, kesan dan strategi menangani permasalahan kurang tumpuan pelajar sekolah menengah di dalam kelas: suatu kajian kualitatif. International Counseling Conference and Work.

Behnamnia, N., Kamsin, A., \& Ismail, M. A. B. (2020). The landscape of research on the use of digital game-based learning apps to nurture creativity among young children: A review. Thinking Skills and Creativity, 37, 100666. https://doi.org/10.1016/j.tsc.2020.100666

Bhuiyan, T., \& Mahmud, I. (2015). Digital game-based education: A meta analysis. International Conference of Inclusive Innovation and Innovative Management. 
Chen, Y.-C. (2017). Empirical study on the effect of digital game-based instruction on students' learning motivation and achievement. Eurasia Journal of Mathematics, Science and Technology Education, 13(7), 3177-3187. https://doi.org/10.12973/eurasia.2017.00711a

Gee, J. P. (2003). What video games have to teach us about learning and literacy. Computers in Entertainment, 1(1), 20-20. https://doi.org/10.1145/950566.950595

Grove, N. P., \& Bretz, S. L. (2012). A continuum of learning: from rote memorization to meaningful learning in organic chemistry. Chemistry Education Research and Practice, 13(3), 201-208. https://doi.org/10.1039/C1RP90069B

Huizenga, J. C. (2017). Digital game-based learning in secondary education [University of Amsterdam]. In Unpublished doctoral dissertation). , Netherlands Retrieved from. https://dare.uva.nl/search?identifier=c2bf59b2-82f0-4791-ae50-981865e955aa

Hwang, G.-J., Chiu, L.-Y., \& Chen, C.-H. (2015). A contextual game-based learning approach to improving students' inquiry-based learning performance in social studies courses. Computers \& Education, 81, 13-25. https://doi.org/10.1016/j.compedu.2014.09.006

Kao, G. Y.-M., Chiang, C.-H., \& Sun, C.-T. (2017). Customizing scaffolds for game-based learning in physics: Impacts on knowledge acquisition and game design creativity. Computers \& Education, 113, 294-312. https://doi.org/10.1016/j.compedu.2017.05.022

Ku, O., Chen, S. Y., Wu, D. H., Lao, A. C. C., \& Chan, T.-W. (2014). The effects of game-based learning on mathematical confidence and performance: High ability vs. low ability. Journal of Educational Technology \& Society, 17(3), 65-78.

Liu, E. Z. F., \& Chen, P.-K. (2013). The effect of game-based learning on students' learning performance in science learning - A case of "Conveyance Go." Procedia - Social and Behavioral Sciences, 103, 1044-1051. https://doi.org/10.1016/j.sbspro.2013.10.430

Mohanty, S. D., \& Cantu, S. (2011). Teaching introductory undergraduate physics using commercial video games. Physics Education, 46(5), 570-577. https://doi.org/10.1088/0031-9120/46/5/009

Novak, J. D. (2010). Learning, creating, and using knowledge: Concept maps as facilitative tools in schools and corporations. Routledge.

Phang, F. A., Abu, M. S., Ali, M. B., \& Salleh, S. (2014). Faktor penyumbang kepada kemerosotan penyertaan pelajar dalam aliran sains: satu analisis sorotan tesis. Sains Humanika, 2(4). https://doi.org/10.11113/sh.v2n4.469

Said, A., \& Normiati, N. (2017). Kualiti pengajaran guru: Isu dan cabaran semasa. Utusan Borneo (Sabah). https://www.pressreader.com/malaysia/utusan-borneosabah/20170419/282643212426811

Sin, N. M., Talib, O., \& Norishah, T. P. (2013). Merging of game principles and learning strategy using apps for science subjects to enhance student interest and understanding. Sains Humanika, 63(2). https://doi.org/10.11113/sh.v63n2.144

Sumintono, B. (2017). Science education in Malaysia: challenges in the 21st century. Jurnal Cakrawala Pendidikan, 36(3). https://doi.org/10.21831/cp.v36i3.16761

Yeh, Y.-T., Hung, H.-T., \& Hsu, Y.-J. (2017). Digital game-based learning for improving students' academic achievement, learning motivation, and willingness to communicate in an English course. 2017 6th IIAI International Congress on Advanced Applied Informatics (IIAI-AAI), 560563. https://doi.org/10.1109/IIAI-AAI.2017.40 